\title{
A CRITICAL EVALUATION OF RED CELL AND PLASMA VOLUME TECHNIQUES IN PATIENTS WITH CIVILIAN INJURIES
}

\author{
BY \\ J. W. L. DAVIES AND E. TOPLEY \\ From the Medical Research Council Industrial Injuries and Burns Research Unit, \\ Accident Hospital, Birmingham, 15
}

(RECEIVED FOR PUBLICATION APRIL 13, 1959)

There is now much evidence to suggest that the major cause of red cell disappearance following trauma is haemorrhage. After severe skeletal injuries, an abating but often clinically important bleed continues for one to four days (Clarke, Davies, Fisher, and Topley, 1959). It can be partly appreciated by the nature of the injury and a judgment of the external blood loss and internal swelling, the early swelling often being entirely due to haemorrhage. The local bleeding can also be assessed indirectly by an estimation of the amount of blood lost from the general circulation. The major cause of "wound shock" is now realized frequently to be a low blood volume, itself caused by blood loss unreplaced by blood transfusion. The effect of the low blood volume can therefore be used as a crude guide to possible haemorrhage. The level of the pulse and blood pressure (Fisher, 1958) and the changing level of the external jugular vein are of limited value as a guide to total blood volume. By these multiple approaches the experienced surgeon often assesses the timing and degree of haemorrhage to within $\frac{1}{2}$ to 1 litre of whole blood $(10-20 \%$ of the normal blood volume of a man $170 \mathrm{~cm}$. tall). But there are occasions where all these guides are too crude; a haemorrhage of a litre or more of blood could be overlooked; and the emergency management of the injury requires a greater precision in the assessment of haemorrhage. It is under these conditions that the laboratory can often assist by measuring the circulating red cell volume. This red cell volume estimate can be compared with the average normal red cell volume estimated from the height. A "red cell volume estimate of haemorrhage" (Topley, Fisher, Davies, and Clarke, 1959) can be obtained by subtracting the volume of blood found to be remaining in the patient from that assumed to be present before injury and adding the volume of blood transfused. Similarly, continuing haemorrhage can be measured by repeated estimates of the red cell volume. Grant and Reeve (1951, e.g., p. 113) emphasized the great clinical value of such estimates in the management of war injuries, especially after operation. Experience in this hospital since the war has shown that repeated red cell volume estimates have made clinical sense when compared with the evidence obtained from the volumes of blood transfused, the evidence of local bleeding, and the later haemoglobin levels (Topley et al., 1959). The evidence suggests that the "red cell volume estimates of haemorrhage" are usually measuring blood loss to the nearest $\frac{1}{2}$ or 1 litre of blood. During the last few years, such red cell volume estimates in selected patients have been used as one part of the evidence on which blood transfusion policy is based. There is no doubt that ${ }^{32} \mathrm{P}$ or ${ }^{51} \mathrm{Cr}$ estimations of red cell volume are of considerable clinical assistance in assessing haemorrhage in selected injuries, especially pelvic or chest injuries, severe multiple injuries, or injuries where there is some conflicting evidence, using the clinical criteria outlined above. It is likely that surgeons will increasingly ask for such a red cell volume estimate of haemorrhage (Topley et al., 1959). For this reason the present paper discusses critically the technique of the red cell volume estimate in patients during the hours and days after injury.

Methods of estimating circulating red cell and plasma volume have been reviewed in terms of their technical details, their accuracy in normal individuals, and the changes measured in disease (Reeve, 1948 ; von Porat, 1951 ; Gregersen, 1951 ; Mollison, 1956; Wiklander, 1956 ; Brown, Hopper, and Wennesland, 1957). Much less evidence is available on the inaccuracies that may be found when disease is present. 
We report here techniques for estimating circulatory volume and an assessment of factors which may cause inaccuracy. The laboratory findings during the hours and days after injury have been compared with those obtained subsequently in the same patients and with those reported by others for normal individuals. In some patients either simultaneous or sequential estimations by different methods have also been compared.

\section{Methods}

Red cell or plasma volume estimations have been made on 86 patients suffering injury from road traffic, domestic, or industrial accidents. At the start of this study in 1953 investigations were carried out between one and four days after injury, when the circulation was probably approaching normal. More recently, with experience of the method, and its more certain clinical value, estimations have been made during the first few hours after injury. During the major part of this study, the first red cell or plasma volume estimation was made between one and 24 hours after injury, and repeated during the ensuing days. Where possible a follow-up estimation was made three to 12 months later. In order to minimize radiation dosage, the total number of estimations on one patient did not exceed four unless there were strong clinical indications for further estimations.

Red Cells Labelled with Radioactive Phosphorus $\left({ }^{32} \mathbf{P}\right)$. - The method was that described by Chaplin (1954) with the following minor modifications:- The heparinized blood from the patient was labelled with 1 to $5 \mu \mathrm{C}$ of ${ }^{32} \mathrm{P}$ for adults instead of 10 to $15 \mu \mathrm{C}$. For children the dose was reduced according to their expected red cell volume. After incubation the labelled cells were centrifuged at 2,500 r.p.m. for three minutes instead of six to eight minutes. The labelled cells were transferred to a special long syringe* containing between 8 and $10 \mathrm{ml}$. and calibrated gravimetrically without the needle. During all manipulations of the red cells strict aseptic precautions were observed. Intravenous injection was usually directly into a vein, but sometimes, particularly during the first few hours after injury, into a blood transfusion drip tubing. If there was the slightest doubt about the efficiency of the intravenous injection, the estimation was abandoned. Samples were taken from a remote vein between nine and 120 minutes after injection. The first sample was always taken within 20 minutes. The red cell volume (R.B.C.V.) was calculated from this 9-20 minute sample using the following formula:

$$
\mathrm{RBCV}=\frac{\mathrm{A} \times \mathrm{B} \times \mathrm{C} \times \mathrm{VH}}{\mathrm{D} \times \mathrm{E} \times 100}
$$

Where $\mathbf{A}=$ volume of labelled cells injected

$\mathrm{B}=$ dilution of standard

$\mathrm{C}=$ count of standard

"From the Medical Supply Association.
VH = venous haematocrit corrected for 으 trapped plasma (Chaplin and Mollison, 1952)

$\mathrm{D}=$ dilution of sample

$\mathrm{E}=$ count of sample after correction for loss of radioactivity from the circulation between injection and sampling by assuming the rate of disappearance to be $0.1 \%$ per minute

With each red cell volume estimation, after washing the labelled cells with plasma saline, the supernatant from the final red cell suspension was removed for counting. The observed supernatant count was compared with the total amount of radioactivity injected, to check that at least $99 \%$ of the injected radioactivity was contained in the red cells. On 10 occasions red cells stored in acid-citrate-dextrose (A.C.D.) solution for transfusion purposes were labelled in the same manner.

All solutions containing ${ }^{32} \mathrm{P}$ were counted in a type M6 liquid G-M counter after lysis of the red cells with saponin. The random distribution error of

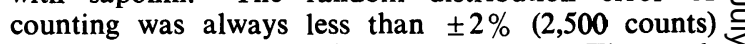
and often less than $\pm 1 \%(10,000$ counts $)$. The stock solution of ${ }^{32} \mathrm{P}$ was always resterilized within 20 minutes of opening.

Red Cells Labelled with Radioactive Chromium $\left({ }^{51} \mathbf{C r}\right)$.-Red cells either from the patient or from a bottle of blood about to be transfused were labelled by the method of Mollison and Veall (1955) with 5 to $50 \mu \mathrm{C}$ according to the expected red cell volume $\stackrel{\nabla}{\mathbb{D}}$ of the patient ; $25 \mu \mathrm{C}$ was commonly used in adults. Intravenous injection and sampling were exactly as for ${ }^{32} \mathrm{P}$-labelled cells. During the preparation of the 3 labelled cells the extracellular radioactivity was removed by three washes with plasma saline for the first 50 experiments, but only two washes were performed on the remaining 60 occasions. The corresponding supernatant radioactivity values have $\frac{\dot{\sigma}}{2}$ been determined as for ${ }^{32} \mathrm{P}$.

All samples containing ${ }^{51} \mathrm{Cr}$ were counted as $10 \mathrm{ml}$. of solution in a scintillation counter having a $\frac{1}{2}$-in. diameter cylindrical thallium activated sodium iodide $\mathrm{O}$ crystal (sensitivity for ${ }^{51} \mathrm{Cr}=9,530$ counts $/$ minute $/ \mu \mathrm{C}$ ).

The calculation of the red cell volume was similar $\frac{7}{8}$ to that of ${ }^{32} \mathrm{P}$, with the exception that no correction was made for loss of radioactivity from the labelled $N$ cells between the time of injection and sampling.

Plasma Proteins Labelled with T-1824 (Evans Blue). 0 -Following the method of Reeve (1948), $1.2 \mathrm{ml}$. of $\tilde{\omega}$ a $2 \%$ solution of T-1824 in distilled water was added $\mathrm{O}$ to $10 \mathrm{ml}$. of sterile saline immediately before use. About $10 \mathrm{ml}$. of this solution was drawn into the syringe and the remainder used as the standard. About $20 \mathrm{ml}$. of blood was taken for a plasma blank and for preparing the standard before the dye was -0 injected. For some years three blood samples were $\underset{\mathbb{D}}{\stackrel{\mathrm{D}}{ }}$ taken at 10-minute intervals after injection from a $\stackrel{?}{+}$ remote vein. More recently only a single sample has $\stackrel{\mathbb{Q}}{\varrho}$ been taken. After determination of the haematocrit $\bar{O}$ the plasma was separated from each of the samples. A standard was prepared containing a known volumeo 
of the original $\mathrm{T}-1824$ solution in a known quantity of the patient's undyed plasma. The optical density of the standard and the plasma was measured at wavelengths of 540,620 , and $680 \mathrm{~m} \mu$ respectively, using a "unicam" SP600 spectrophotometer. The patient's undyed plasma was used as a blank against which the optical density of the dyed sample was compared. The relationship between the low optical density of the dye in plasma at $680 \mathrm{~m} \mu$ to its high optical density at $620 \mathrm{~m} \mu$ has been plotted for each batch of dye. The $680 \mathrm{~m} \mu \mathrm{T}-1824$ optical density can be read off the graph on the assumption that all the $620 \mathrm{~m} \mu$ optical density is due to T-1824. Since the extra opacity has almost the same absorption at $620 \mathrm{~m} \mu$ and $680 \mathrm{~m} \mu$ an appropriate correction can be calculated for the T-1824 absorption at $680 \mathrm{~m} \mu$. Thus:

T-1824 O.D. $620 \mathrm{~m} \mu=$ O.D. $620 \mathrm{~m} \mu-$ O.D. $680 \mathrm{~m} \mu$ + T-1824 O.D. $680 \mathrm{~m} \mu$, where O.D. = optical density.

The $540 \mathrm{~m} \mu$ reading was used to check that the level of haemoglobin was not sufficient to affect the $620 \mathrm{~m} \mu$ reading. The plasma volume (PV) was calculated from the following equation.

$$
\mathrm{PV}=\frac{\mathrm{F} \times \mathrm{G} \times \mathrm{H}}{\mathrm{J}}
$$

Where $\mathrm{F}=$ volume of $\mathrm{T}-1824$ solution injected

$\mathrm{G}=$ dilution of standard

$\mathbf{H}=\mathrm{T}-1824$ optical density of standard

$\mathbf{J}=\mathrm{T}-1824$ optical density of sample after correction for the loss of dye from the circulation between injection and sampling by assuming the rate of disappearance to be $0.1 \%$ per minute

Human Albumin Labelled with Radioactive Iodine $\left.{ }^{131} I\right)$.- Human albumin was labelled with ${ }^{131} I$ to a level of $1 \mu \mathrm{C}$ per mg. of albumin and not more than one atom of iodine per molecule of albumin by the following modifications of the technique of Veall, Pearson, and Hanley (1955). The iodine was liberated from the iodide-iodate mixture with $\mathbf{N}$ sulphuric acid instead of $\mathbf{N}$ hydrochloric acid, and the yield of labelled albumin was improved by washing the resin column with 0.5 to $1.0 \mathrm{ml}$. unlabelled albumin after the radioactive material had passed down the column.

For a plasma volume estimation, $3-5 \mu \mathrm{C}$ of labelled albumin solution was diluted with saline before injection. Blood samples were taken from a remote vein usually 15,30 , and 45 minutes after injection. The specific radioactivity of the plasma was determined either in separated plasma or in whole blood with correction for the haematocrit. The radioactive standards were prepared by diluting a sample of the injected material with distilled water containing $0.05 \%$ potassium iodide and $1 \%$ unlabelled albumin to minimize the loss of active material on glass surfaces (Reeve, 1957).

The plasma volume was calculated from the dilution of the radioactive material using a formula analogous to that used with labelled red cells. The ${ }^{131} I$ was usually counted in a liquid scintillation counter, as this equipment has a greater sensitivity to the $\gamma$ radiation of ${ }^{131} I$ than the M6 liquid counter has for the $\beta$ radiation emitted by this isotope.

Other Methods and Calculations.-The venous haematocrit was estimated by centrifuging heparinized venous blood in Wintrobe tubes for either 30 or 55 minutes at 3,000 r.p.m. in a centrifuge with head radius $15 \mathrm{~cm}$. Appropriate corrections for trapped plasma were applied (Chaplin and Mollison, 1952).

The "blood volume" has been taken as the red cell volume plus the plasma volume as calculated above when both have been measured. The blood volume has also been calculated from the venous haematocrit and either the red cell or plasma volume. An adjustment has been made for the difference between the body and venous haematocrits.

The body haematocrit $=$

$$
\frac{\text { red cell volume }}{\text { red cell volume }+ \text { plasma volume }}
$$

An average normal ratio between the body and venous haematocrits of 0.9 has been assumed, so that :

$$
\begin{gathered}
\text { Blood volume }=\frac{\text { red cell volume } \times 100}{0.9 \times \text { venous haematocrit }} \\
\text { or } \frac{\text { plasma volume } \times 100}{100-(0.9 \times \text { venous haematocrit })}
\end{gathered}
$$

Similarly the red cell volume has been calculated indirectly from the plasma volume and the venous haematocrit.

Red cell volume $=$

$\left(\frac{\text { plasma volume } \times 100}{100-(0.9 \times \text { venous haematocrit })}-\right.$ plasma volume $)$

Counting Mixtures of Two Radioactive Isotopes.It was possible to use ${ }^{32} \mathrm{P}$ - and ${ }^{51} \mathrm{Cr}$-labelled red cells simultaneously due to the differing radiation characteristics of these isotopes. The pure $\beta$ radiation of ${ }^{32} \mathrm{P}$ is efficiently detected by the G-M counter and not detected by the scintillation counter, whilst the $\gamma$ and $x$ radiation of ${ }^{51} \mathrm{Cr}$ is efficiently detected by the scintillation counter but makes only a slight contribution (less than 1\%) to the counts in the G-M tube.

The use of ${ }^{51} \mathrm{Cr}$ and ${ }^{131} \mathrm{I}$ necessitated a correction factor for the $\gamma$ radiation of one isotope interfering with that of the other. The usual procedure was to make the estimations sequentially, the ${ }^{131}$ I albumin being injected after the 15-minute sample for the ${ }^{51} \mathrm{Cr}$ red cell volume estimation had been taken. On a few occasions the isotopes were injected simultaneously, and then the $\gamma$ activity of a sample of plasma $\left({ }^{131} \mathrm{I}\right.$ alone) was subtracted from the $\gamma$ activity of whole blood $\left({ }^{51} \mathrm{Cr}\right.$ and $\left.{ }^{131} \mathrm{I}\right)$ with appropriate correction for the haematocrit.

\section{Results}

An assessment of factors which may cause inaccuracy will first be described, the observations within 48 hours of injury being compared with 
those made later. In the second section will be given the results of simultaneous estimations using various pairs of methods.

Possible Causes of Inaccuracy.-Certain factors may cause inaccuracy, namely, the radioactivity level of the supernatant, and the adequacy of intravascular mixing and survival of the labelled material.

Radioactivity Level of the Supernatant.The radioactivity in the plasma saline in which the labelled cells were suspended ("supernatant") has been expressed as a percentage of the total quantity of radioactivity injected (Table I), and

TABLE I

RADIOACTIVITY LEVEL OF PLASMA SALINE (SUPERNATANT) IN WHICH THE LABELLED CELLS WERE SUSPENDED EXPRESSED AS PERCENTAGE OF INJECTED

\begin{tabular}{|c|c|c|c|c|c|}
\hline $\begin{array}{l}\text { No. of } \\
\text { Washes }\end{array}$ & Isotope & $\begin{array}{c}\text { No. of } \\
\text { Observa- } \\
\text { tions }\end{array}$ & $\mid \begin{array}{c}\text { Mean } \\
\text { Percentage } \\
\text { in } \\
\text { Supernatant }\end{array}$ & $\begin{array}{c}\text { No. of } \\
\text { Observa- } \\
\text { tions } \\
\text { Over } 1 \%\end{array}$ & $\begin{array}{c}\text { Observations } \\
\text { Over } 1 \% \text { as } \% \\
\text { Total } \\
\text { Observations }\end{array}$ \\
\hline $\begin{array}{c}\text { Patient's } \\
3 \\
3 \\
2\end{array}$ & $\begin{array}{l}{ }^{32} \mathrm{P} \\
{ }^{51} \mathrm{Cr} \\
{ }^{51} \mathrm{Cr}\end{array}$ & $\begin{array}{c}\text { lled during } \\
107 \\
35 \\
28\end{array}$ & \begin{tabular}{|c|} 
the first 48 ho \\
0.57 \\
0.27 \\
0.40
\end{tabular} & $\begin{array}{rr}\text { urs } & \\
14 \\
1 \\
\\
\end{array}$ & $\begin{array}{r}13 \\
3 \\
8\end{array}$ \\
\hline $\begin{array}{c}\text { Patient's } \\
\mathbf{3} \\
3 \\
2\end{array}$ & 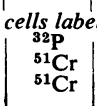 & $\begin{array}{l}\text { lled after } t \\
175 \\
6 \\
5\end{array}$ & \begin{tabular}{|} 
he first 48 hour \\
0.57 \\
0.26 \\
0.31
\end{tabular} & $\begin{array}{r}16 \\
0 \\
0\end{array}$ & $\begin{array}{l}9 \\
0 \\
0\end{array}$ \\
\hline $\begin{array}{c}\text { Stored ce } \\
3 \\
3 \\
2\end{array}$ & $\begin{array}{l}\text { lls labelle } \\
\begin{array}{l}{ }^{32} \mathrm{P} \\
{ }^{51} \mathrm{Cr} \\
{ }^{51} \mathrm{Cr}\end{array} \mid\end{array}$ & $\begin{array}{l}10 \\
50 \\
25\end{array}$ & $\begin{array}{l}3 \cdot 3 \\
0 \cdot 28 \\
0 \cdot 41\end{array}$ & $\begin{array}{r}10 \\
1 \\
1\end{array}$ & $\begin{array}{r}100 \\
2 \\
4\end{array}$ \\
\hline
\end{tabular}

the results obtained during the first 48 hours after injury compared with those obtained later. A comparison is made between different isotopes, the source of the red cells that were labelled, and the number of washes with plasma saline. It can be seen that the labelling of red cells stored in A.C.D. solution with ${ }^{32} \mathrm{P}$ was unsatisfactory, as the radioactivity in the supernatant was always more than $1 \%$ of the total in the injected red cell suspension. When the patient's cells were labelled with either ${ }^{32} \mathrm{P}$ or ${ }^{51} \mathrm{Cr}$ there was no difference between the mean values during the first 48 hours and those made later. There were, however, significantly more results above $1 \%$ when ${ }^{32} \mathrm{P}$ was used $(30 / 282$ or $11 \%)$ than when ${ }^{5} \mathrm{Cr}$ was used $(3 / 74$ or $4 \%)(\sigma=0.575, \mathrm{t}=3.30$, $\mathrm{P}=0.001$ ).

The rate of leakage of ${ }^{51} \mathrm{Cr}$ from labelled stored red cells has been investigated in vitro as shown in Table II. Standing at room temperature for up to four hours produced no excessive leakage except when the cells had been stored for more than four weeks in A.C.D. solution.
TABLE II

RATE OF LEAKAGE OF ${ }^{51} \mathrm{Cr}$ FROM LABELLED CELLS EXPRESSED AS A PERCENTAGE OF TOTAL ACTIVITY INITIALLY IN THE CELLS

\begin{tabular}{l|c|c|c|c}
\hline \multirow{2}{*}{$\begin{array}{c}\text { Time } \\
\text { after } \\
\text { Labelling }\end{array}$} & \multicolumn{4}{|c}{ Age of Stored Cells } \\
\cline { 2 - 5 } & 0 Days & 12 Days & 22 Days & 30 Days \\
\hline 0 hour & 0.20 & 0.40 & 0.20 & 0.65 \\
1 , & 0.36 & 0.49 & 0.34 & 0.73 \\
2 hours & 0.43 & 0.62 & 0.52 & 1.20 \\
$3,$, & 0.69 & 0.98 & 0.53 & 1.20 \\
$4,$, & 0.79 & 0.87 & 0.59 & 1.12 \\
\hline
\end{tabular}

Adequacy of Intravascular Mixing and Survival of Labelled Material in the Circulation.-The changing levels of radioactivity in the circulation have been plotted for each patient as the concentration of label per unit volume of red cells or plasma (log. scale) against the time after injection (linear scale). Extrapolation of the best straight line through these points to zero time gives the theoretical initial concentration $(100 \%)$, and other observations are expressed as a percentage of this value. The mean of all the percentages at each time interval after injection together with the standard deviations are plotted in Figs. 1a, $1 \mathrm{~b}, 1 \mathrm{c}$, and 1d for each type of label and for observations made before and after 48 hours of injury. Fifty-four estimations on 51 patients have been made with ${ }^{51} \mathrm{Cr}, 97$ estimations on 52 patients with ${ }^{32} \mathrm{P}$, and 79 estimations on 32 patients with $\mathrm{T}-1824$. The best straight line has been drawn through the mean values to indicate the average rate of disappearance. The mean rate of disappearance of labelled red cells during 10 to 60 minutes after injection was always greater during the first 48 hours after injury compared with that observed later, but the rate never exceeded $0.3 \%$ per minute.

It can be seen (Table III) that with ${ }^{32} \mathrm{P},{ }^{51} \mathrm{Cr}$, and corrected T-1824 only one out of 189 results taken between nine and 15 minutes after injection varied from the mean value by more than $\pm 15 \%$. With ${ }^{32} \mathrm{P}$-labelled patients' cells and ${ }^{5}$ Cr-labelled patients' or stored cells, the number of observations outside these limits increased as the time between injection and sampling increased. More of the ${ }^{32} \mathbf{P}$ observations exceeded the $\pm 15 \%$ limits when they were made later than 48 hours after injury compared with earlier observations. With ${ }^{51} \mathrm{Cr}$ neither the time after injury nor the source of the cells appeared to affect the scatter.

With T-1824 the improvement after correction for extra opacity using the $680 \mathrm{~m} \mu$ reading is very marked. No observation then exceeded $\pm 15 \%$ of the mean value, whereas without 


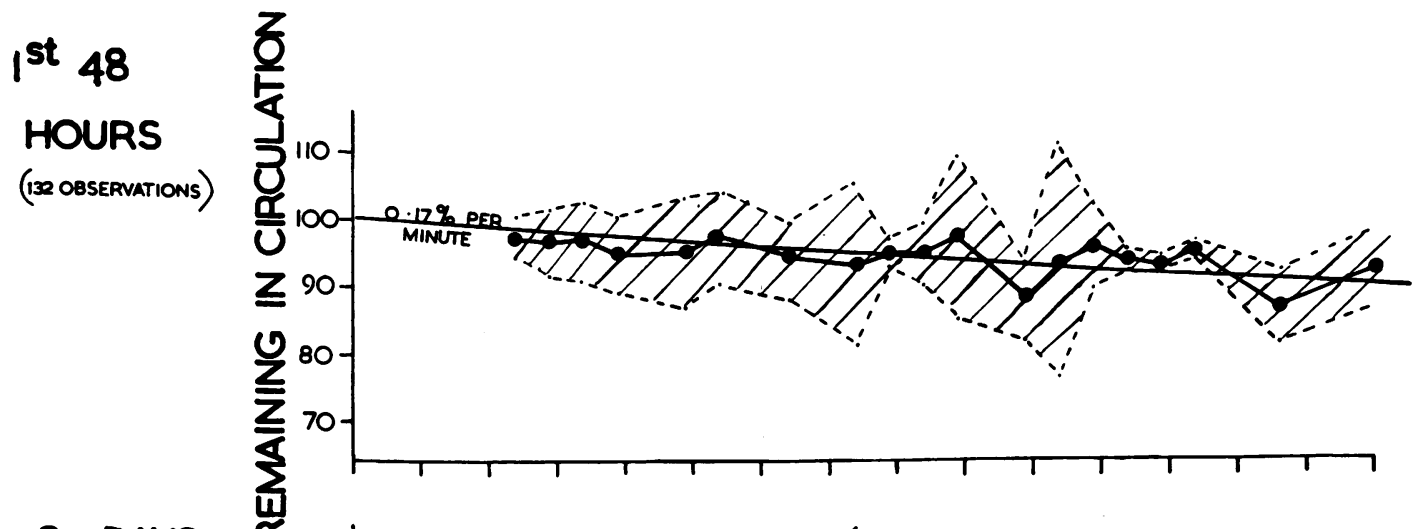

3 DAYS (4I CBSERMTIONS)

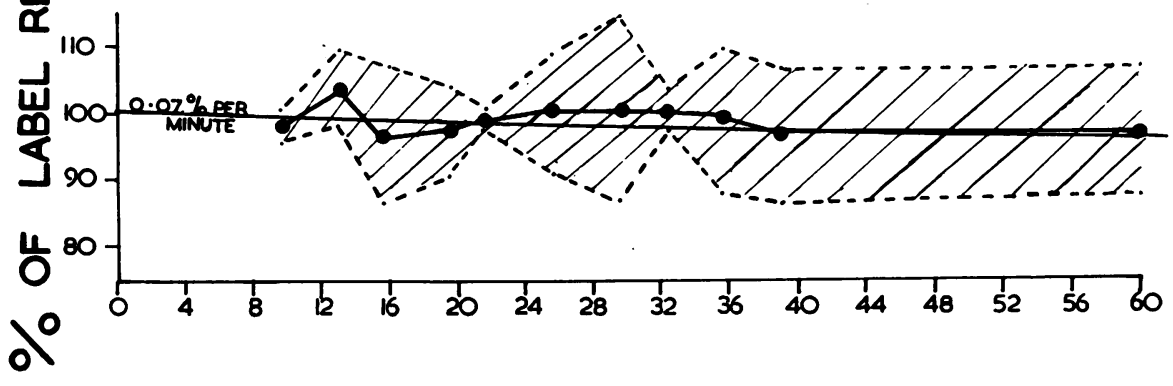

FIG. 1a.-The mean rate of disappearance of ${ }^{51} \mathrm{Cr}$.

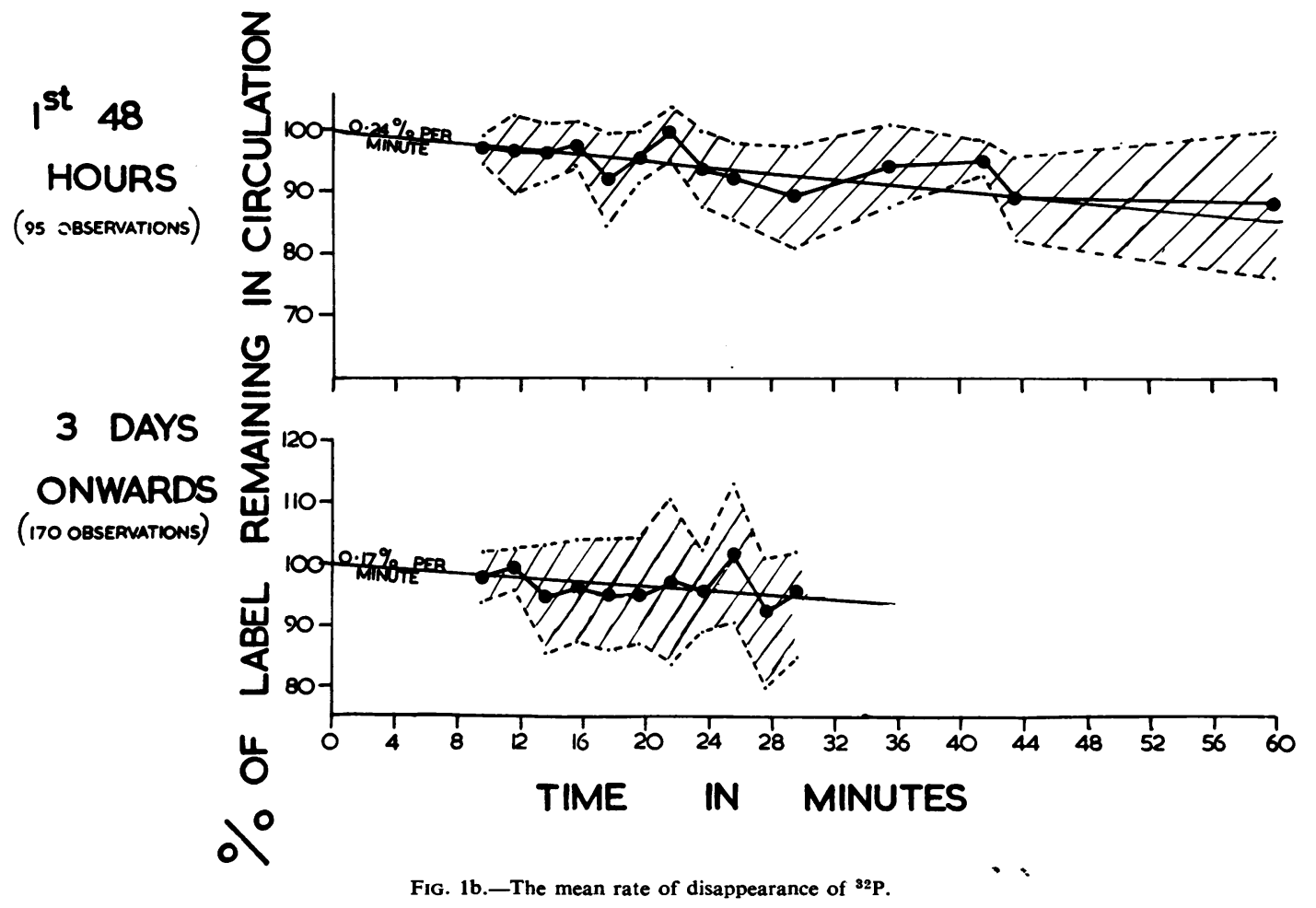

Fig. 1b.-The mean rate of disappearance of ${ }^{32} \mathrm{P}$. 


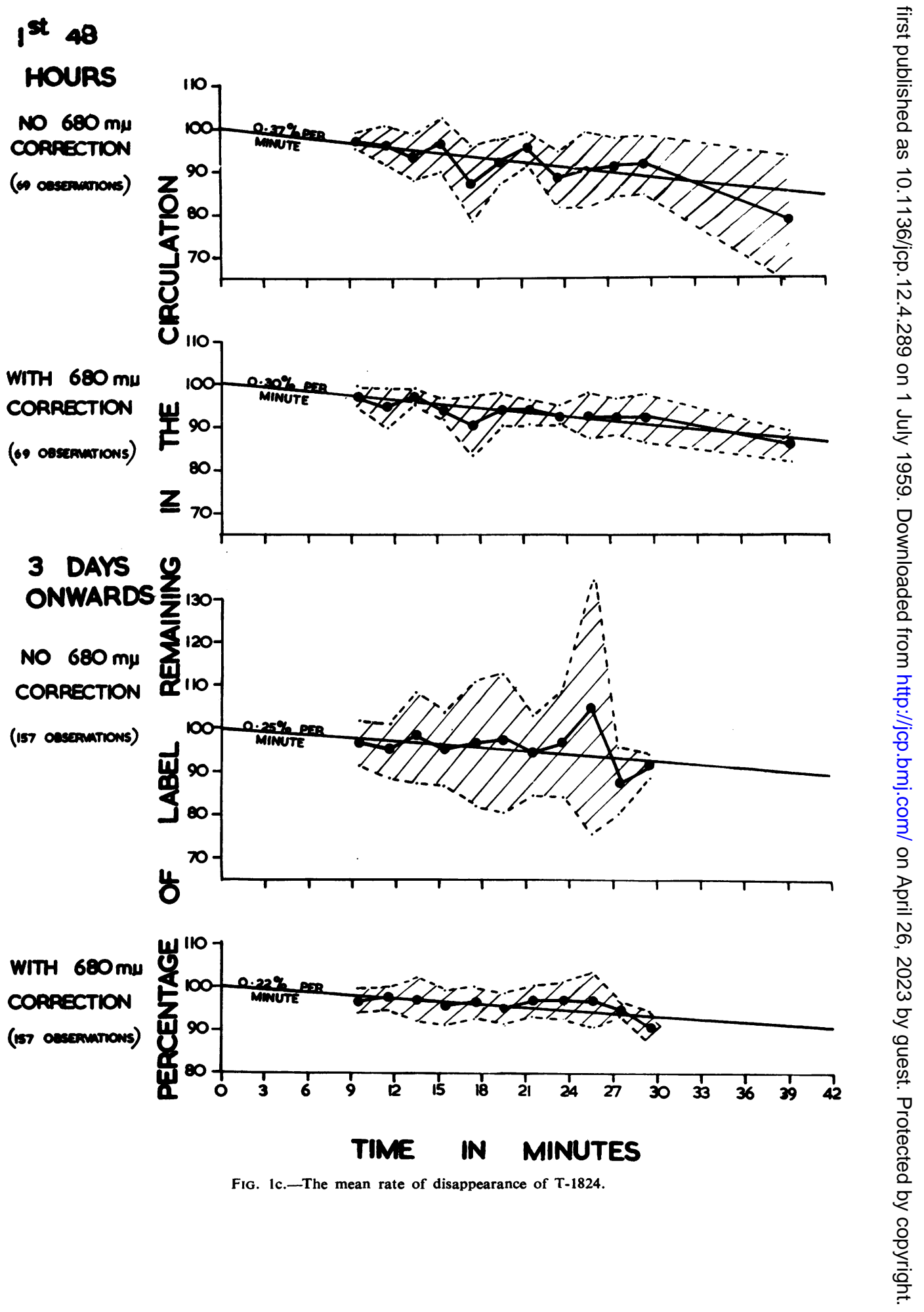




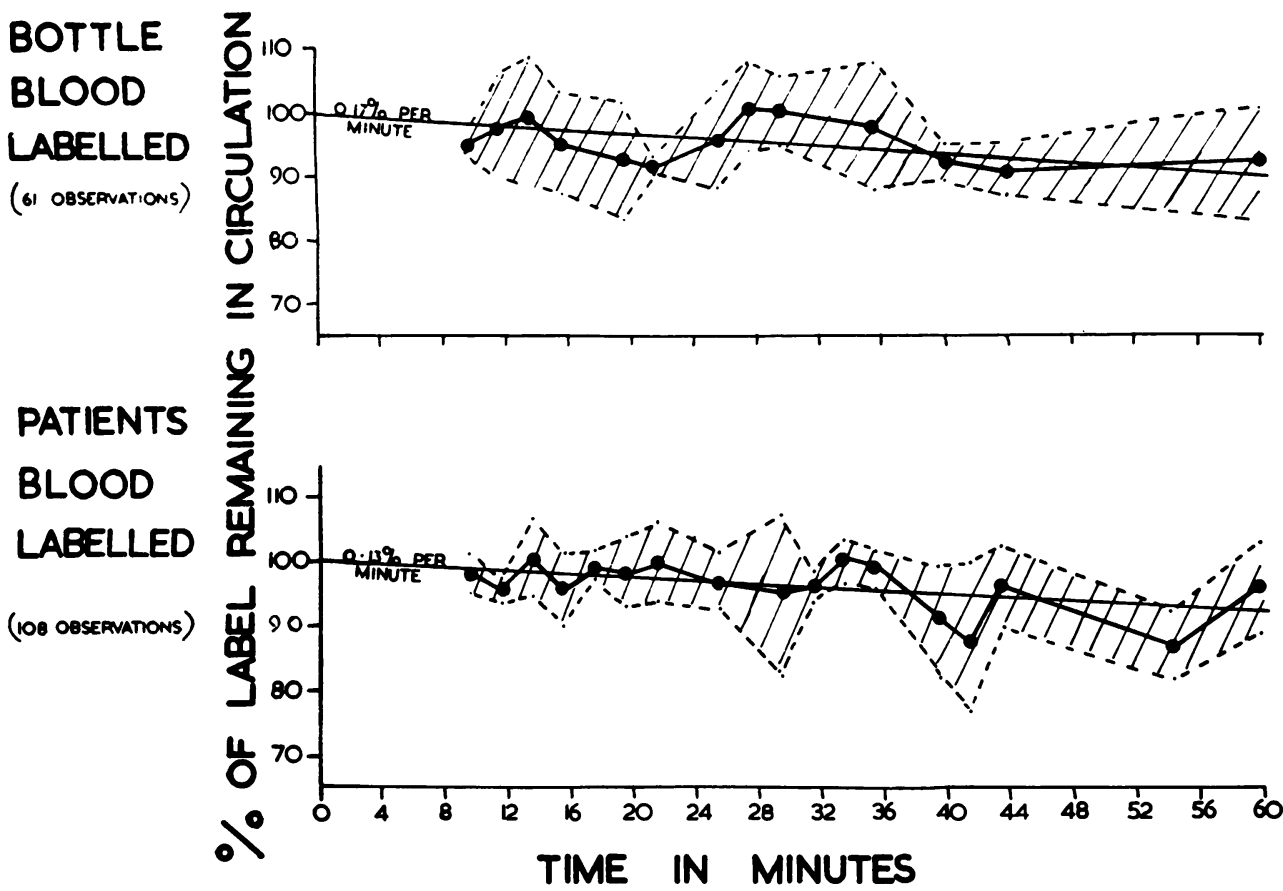

FIG. 1d.-The mean rate of disappearance of ${ }^{51} \mathrm{Cr}$ from labelled transfusion blood compared with that from labelled patient's blood.

TABLE III

NUMBER OF OBSERVATIONS EXCEEDING $15 \%$ OF MEAN VALUES ILLUSTRATED IN FIG. 3 AND POSSIBLE SAMPLING ERRORS AFTER INJECTION OF LABELLED

\begin{tabular}{|c|c|c|c|c|c|c|}
\hline \multirow[b]{2}{*}{$\begin{array}{l}\text { Labelling } \\
\text { Agent }\end{array}$} & & \multirow[b]{2}{*}{ Totals } \\
\hline & & $\begin{array}{l}9-14 \\
\text { min. }\end{array}$ & $\begin{array}{c}15-20 \\
\text { min. }\end{array}$ & $\begin{array}{c}21-30 \\
\text { min. }\end{array}$ & $\begin{array}{c}31-40 \\
\text { min. }\end{array}$ & \\
\hline \multirow{2}{*}{${ }^{51} \mathrm{Cr}$} & \multirow{2}{*}{$\begin{array}{l}\text { Before } \\
48 \text { hours } \\
\text { After } \\
48 \text { hours }\end{array}$} & $0 / 28$ & $2 / 36$ & $2 / 27$ & $2 / 24$ & $6 / 115$ \\
\hline & & $0 / 8$ & $0 / 10$ & $2 / 12$ & $0 / 7$ & $2 / 37$ \\
\hline \multirow[t]{2}{*}{${ }^{32} \mathbf{P}$} & \multirow{2}{*}{\begin{tabular}{|l|} 
Before \\
48 hours \\
After \\
48 hours
\end{tabular}} & $0 / 22$ & $0 / 32$ & $0 / 24$ & $0 / 7$ & $0: 85$ \\
\hline & & $1 / 57$ & $5 / 70$ & $8 / 41$ & - & $14 / 168$ \\
\hline \multirow[t]{2}{*}{${ }^{51} \mathrm{Cr}$} & \multirow{2}{*}{$\begin{array}{c}\text { Patient's } \\
\text { cells } \\
\text { labelled } \\
\text { Stored } \\
\text { cells } \\
\text { labelled }\end{array}$} & $0 / 27$ & $0 / 28$ & $2 / 21$ & $1 / 20$ & $3 / 96$ \\
\hline & & $0 / 9$ & $2 / 18$ & $2 / 18$ & $2 / 11$ & $6 / 56$ \\
\hline \multirow{2}{*}{$\begin{array}{c}\mathrm{T}-1824 \\
\text { with } \\
680 \mathrm{~m} \mu \\
\text { correction }\end{array}$} & \multirow{2}{*}{\begin{tabular}{|l|} 
Before \\
48 hours \\
After \\
48 hours
\end{tabular}} & $0 / 20$ & $0 / 24$ & $0 / 22$ & - & $0 / 66$ \\
\hline & & $0: 54$ & $0 / 67$ & $0 / 36$ & - & $0 / 157$ \\
\hline \multirow{2}{*}{$\left.\begin{array}{c}\mathrm{T}-1824 \\
\text { without } \\
680 \mathrm{~m} \mu \\
\text { correction }\end{array}\right\}$} & \multirow{2}{*}{\begin{tabular}{|l|} 
Before \\
48 hours \\
After \\
$\mathbf{4 8}$ hours
\end{tabular}} & $0 / 20$ & $0 / 24$ & $0 / 22$ & - & $0 / 66$ \\
\hline & & $3 / 54$ & $9 / 67$ & $7 / 36$ & - & $19 / 157$ \\
\hline
\end{tabular}

the correction 19 out of 213 results exceeded these limits. The difference between the variances is highly significant $(P=0.001)$.

Variations in Ratio between Body and Venous Haematocrits.-Ninety-six simultaneous estima- tions of red cell and plasma volume using either ${ }^{32} \mathrm{P}$ or ${ }^{51} \mathrm{Cr}$ and $\mathrm{T}-1824$ enabled the body haematocrit to be calculated and hence its ratio to the venous haematocrit. The ratios (Table IV) have been considered at four periods after injury: the first (up to six hours after injury) when the circulation is most likely to be abnormal, the second (seven to 48 hours) during the post-operative period, the third (three to 30 days) when anaemia may be present in some patients, and finally (one to 12 months) when the circulation has probably returned to a normal condition. The mean ratio was 0.915 during the first 48 hours after injury compared with 0.948 later, but the scatter of the results is such that this difference is not significant $(\sigma=0.0641$, $t=2.04, P=0.05)$. There is also no significant difference between the first and second periods $(\sigma=0.0583, t=1.602, \quad P=0.10)$. There was no greater range of variation during the first 48 hours than later, and the total range of all the results was $\pm 13 \%$. Only six of the 96 observations lay outside $\pm 10 \%$, and only 30 of the 96 outside $\pm 5 \%$ of the mean value of 0.937 . During the first six hours after injury the ratios did not exceed $\pm 9 \%$ of the mean value.

Simultaneous Estimations of Red Cell and Plasma Volume.-These estimations were made by 
$a$
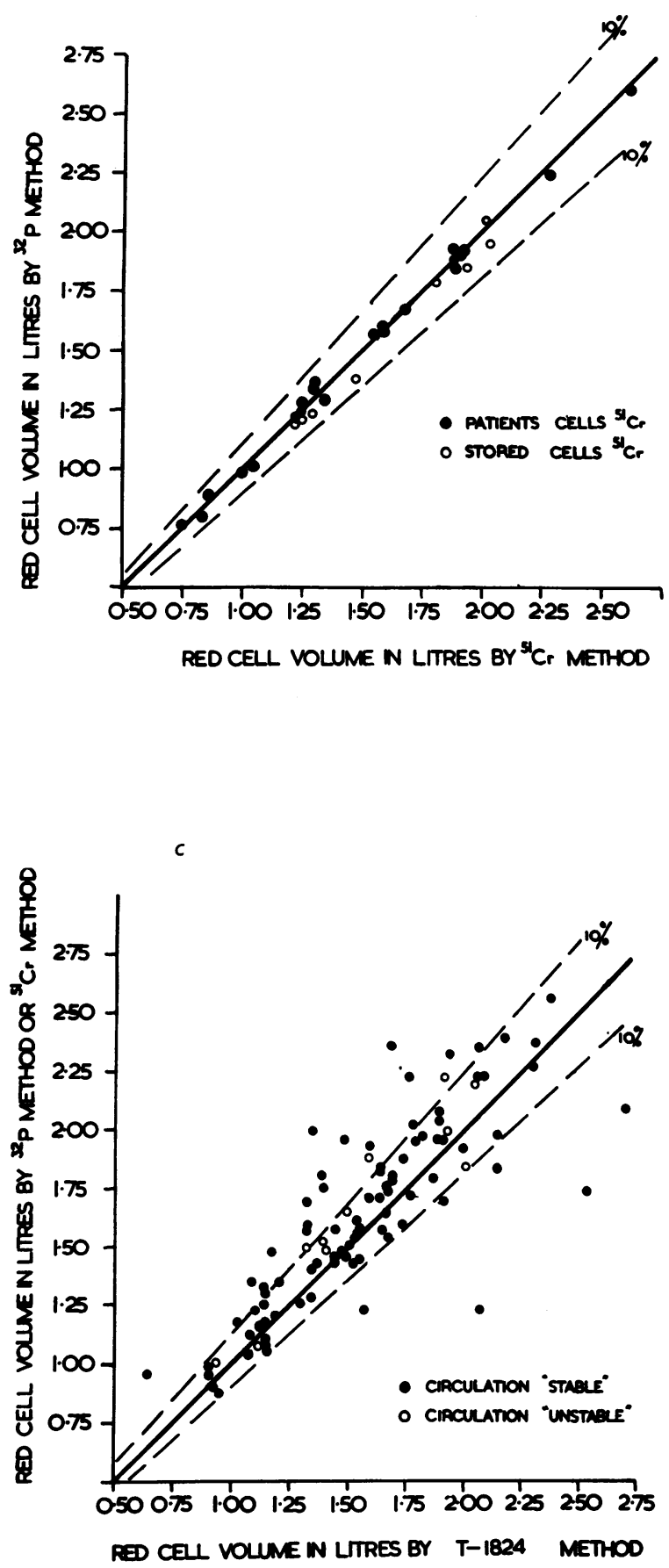

b

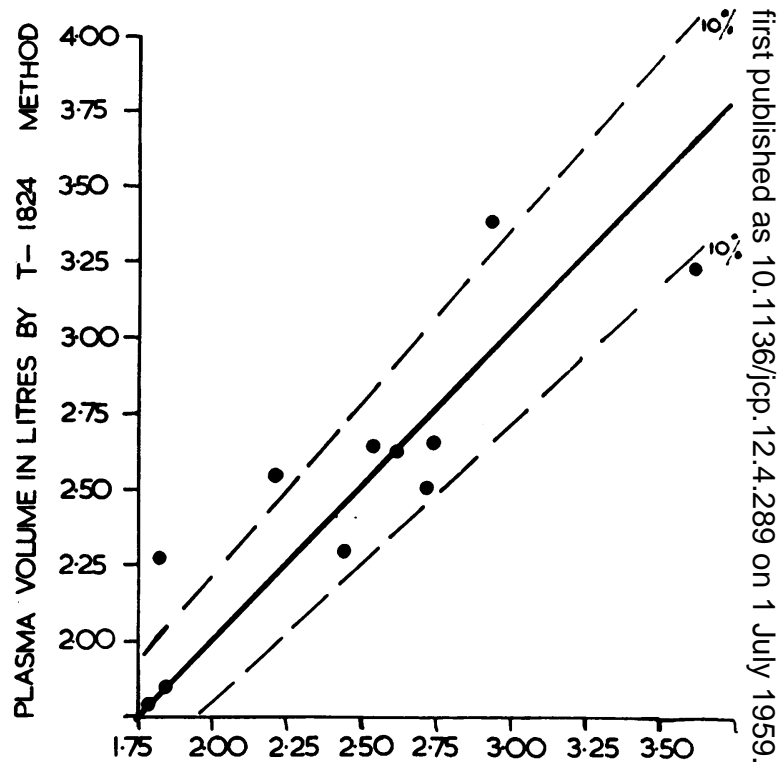

PLASMA VOLUME IN LITRES BY ${ }^{13 L}$ I ALEUMIN

Fig. 2. Simultaneous estimations of red cell and plasma volume using a number of methods. The scatter of the results around the line of equivalence is shown together with the $\pm 10 \%$ limits.

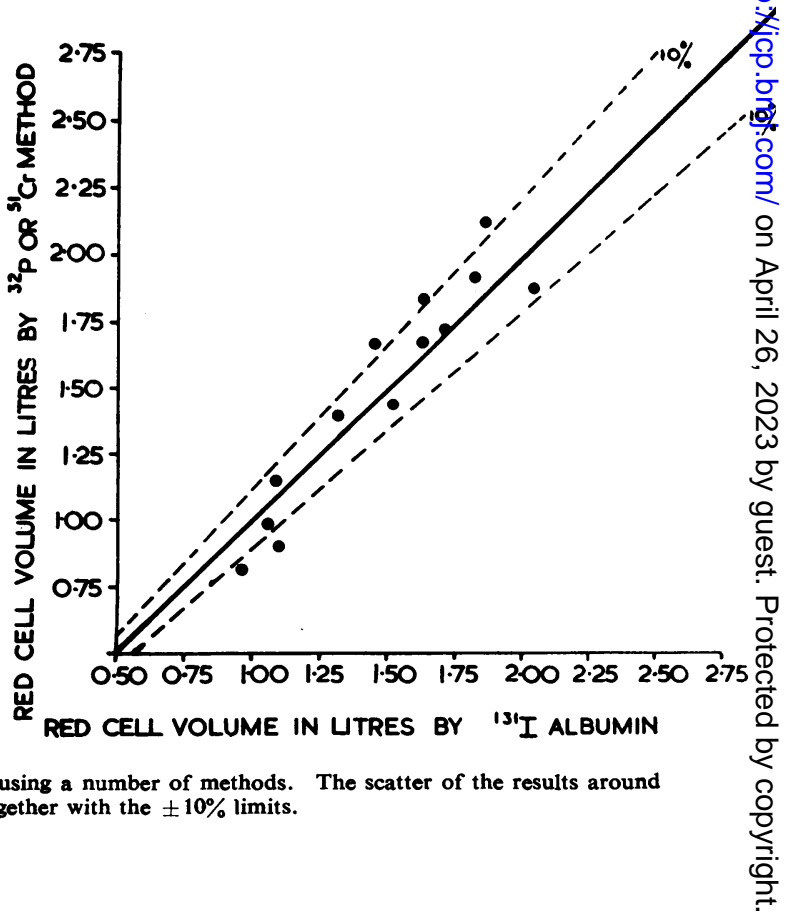


TABLE IV

BODY/VENOUS HAEMATOCRIT RATIOS

\begin{tabular}{|c|c|c|c|c|}
\hline $\begin{array}{c}\text { First } \\
\text { Six Hours } \\
\text { after Injury }\end{array}$ & $\begin{array}{l}7-48 \\
\text { Hours }\end{array}$ & $\begin{array}{l}3-30 \\
\text { Days }\end{array}$ & \multicolumn{2}{|c|}{$\begin{array}{c}1-12 \\
\text { Months }\end{array}$} \\
\hline $\begin{array}{l}0.97 \\
0.85 \\
0.97 \\
0.92 \\
0.95 \\
1.00 \\
0.97 \\
0.88 \\
0.95 \\
0.94 \\
0.89 \\
0.94 \\
0.93 \\
12.16 \\
\mathrm{n}=13 \\
\bar{x}=0.935\end{array}$ & $\begin{array}{l}0.96 \\
0.77 \\
0.82 \\
0.92 \\
0.88 \\
0.95 \\
0.94 \\
0.89 \\
0.77 \\
0.99 \\
0.91 \\
0.88 \\
1.03 \\
0.94 \\
0.85 \\
0.91 \\
0.91 \\
0.90 \\
16.22 \\
\mathbf{n}=18 \\
\overline{\mathbf{x}}=0.901\end{array}$ & $\begin{array}{l}0.93 \\
1.00 \\
1.06 \\
1.00 \\
1.02 \\
0.97 \\
0.91 \\
0.87 \\
0.85 \\
0.90 \\
0.84 \\
0.88 \\
0.91 \\
0.89 \\
0.95 \\
0.94 \\
1.24 \\
0.93 \\
0.93 \\
0.98 \\
0.90 \\
0.96 \\
0.94 \\
0.90 \\
22.70 \\
\mathrm{n}=24 \\
\bar{x}=0.946\end{array}$ & $\begin{array}{l}0.89 \\
0.96 \\
1.00 \\
0.88 \\
1.00 \\
0.92 \\
0.99 \\
0.96 \\
0.93 \\
0.97 \\
0.94 \\
0.99 \\
0.92 \\
0.90 \\
0.92 \\
0.94 \\
0.93 \\
1.01 \\
0.92 \\
0.94\end{array}$ & $\begin{array}{c}0.95 \\
0.89 \\
0.99 \\
0.90 \\
0.86 \\
0.90 \\
0.89 \\
1.02 \\
0.90 \\
0.95 \\
0.95 \\
0.96 \\
0.93 \\
0.89 \\
0.97 \\
0.95 \\
1.03 \\
0.97 \\
0.96 \\
1.18 \\
0.95 \\
38.90 \\
\mathrm{n}=41 \\
\bar{x}=0.949\end{array}$ \\
\hline
\end{tabular}

two methods in parallel on the same subjects. The labelled materials were injected from two different syringes with not more than one-minute intervals between the injections. The amount of the two labels was determined separately in the sample of blood taken after mixing was complete. The results have been plotted to show their variance from the line of complete equivalence.

Red Cells from Patient Labelled with Both ${ }^{32} \mathrm{P}$ and ${ }^{51} \mathrm{Cr}$.- The 19 estimations in this group are shown as solid circles in Fig. 2a. Fourteen of the 19 estimations were made within 24 hours of injury. All agree within a range of $\pm 5 \%$ of the line of equivalence (S.D. $=2.76, \sigma=0.63, P=0.5-$ 0.6).

Red Cells from Patient Labelled with ${ }^{32} P$ and Red Cells from Transfusion Bottle Labelled with ${ }^{51} \mathrm{Cr}$. - The 11 estimations (hollow circles Fig. 2a) were made within 24 hours of injury. The red cell volumes determined with ${ }^{51} \mathrm{Cr}$-labelled stored cells are slightly greater than those with ${ }^{32} \mathrm{P}$ labelled patients' cells. All the results lie within a range of $+9 \%$ to $-1 \%$ of the line of equivalence. Older cells tend to give higher estimations (Fig. 3). The regression line was fitted from $y=-1.147+0.426 x$. Only a small error results from using stored cells up to 10 days old.
Simultaneous Estimations of Red Cell and Plasma Volume Using ${ }^{32} \mathrm{P}$ - or ${ }^{51} \mathrm{Cr}$-labelled Red Cells and T-1824 or ${ }^{131}$ I-labelled Albumin.Although the labelled red cells and albumin were usually injected with an interval between them of 15 to 20 minutes, on one occasion the interval was only one minute. With the sequential estimations the red cells were injected before the labelled albumin, so that mixing and sampling for the measurement of the red cell volume occurred before the plasma volume estimation.

Red cells labelled with ${ }^{32} \mathrm{P}$ and $\mathrm{T}-1824$ were used on 90 occasions to estimate simultaneously the red cell and plasma volume. All the estimations were made at least 24 hours after

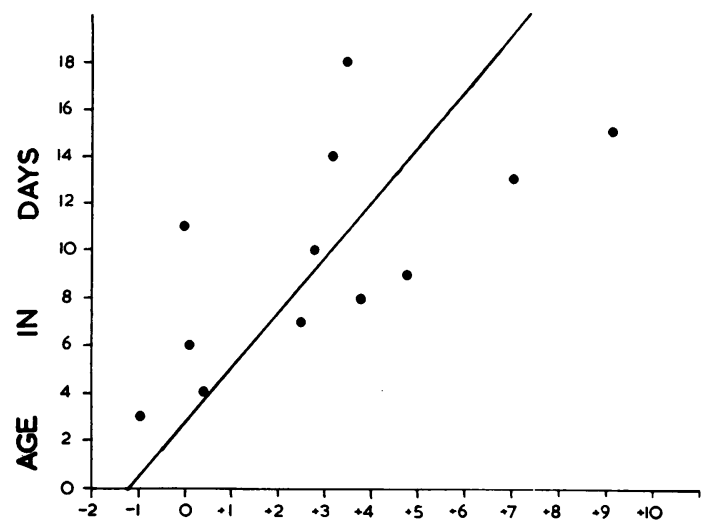

\section{$\%$ VARIATION BEtweEn Estimations}

FIG. 3.-The relationship between the period of storage of red cells in A.C.D. solution before labelling with ${ }^{51} \mathrm{Cr}$ and the difference between simultaneous red cell volume estimations using ${ }^{32} \mathrm{P}$ labelled patient's cells and ${ }^{51} \mathrm{Cr}$ labelled stored cells.

injury when the circulation was thought to be "stable" (Fig. 2c). When the red cell volume calculated from the plasma volume and the haematocrit were compared with the directly estimated red cell volume, the two methods differed by amounts considerably greater than those found with the simultaneous ${ }^{32} \mathrm{P}$ and ${ }^{51} \mathrm{Cr}$ estimations. Inspection of the data shows that around the line of equivalence one-third of the observations agree to within $\pm 5 \%$; two-thirds of the observations agree to within $\pm 10 \%$; three-quarters of the observations agree to within $\pm 15 \%$; five-sixths of the observations agree to within $\pm 20 \%$. The red cell volume calculated from the plasma volume and the haematocrit was on average lower than that directly estimated.

The scatter of the results was no greater when the simultaneous estimations were made within four hours of injury. 
The 13 simultaneous estimations using ${ }^{131} \mathrm{I}-$ labelled albumin and ${ }^{51} \mathrm{Cr}$-labelled red cells also showed a considerable scatter (Fig. 2d).

Simultaneous Plasma Volume Estimations Using T-1824 and ${ }^{131}$ I-labelled Human Albumin. -The two labelled materials injected within one minute of each other gave results (Fig. 2b) which agreed to within $\pm 20 \%$ and seven of the 11 agreed to within $\pm 10 \%$. Only three of the estimations were made later than 48 hours after injury.

\section{Discussion}

This study has revealed variations in the amount of radioactivity in the suspending plasma saline, variations in the mean rate of disappearance of the labelled materials from the circulation, and differences between two methods used in parallel. These variations will be compared with the findings in normal individuals and discussed in terms of their probable effect on the accuracy of red cell volume measurement after injury.

Level of Radioactivity in Supernatant.-This indicates the amount of extracellular radioactivity found in the red cell suspension before its intravenous injection. Theoretically if the cells lose no more radioactivity later a supernatant level of $1 \%$ should produce a $1 \%$ error in the result. In practice, however, Chaplin (1954) found a $10 \%$ error in the red cell volume estimation when the supernatant level was only slightly more than $1 \%$. We have found that when cells stored in A.C.D. solution were labelled with ${ }^{32} \mathrm{P}$ on average $3.3 \%$ of the radioactivity was in the supernatant. These high supernatant values were associated with very gross errors in the red cell volume when the latter was compared with a simultaneous ${ }^{51} \mathrm{Cr}$.

Although supernatant values above $1 \%$ were occasionally found with both isotopes using the routine methods described above, there was no significant difference between the values determined within 48 hours of injury compared with those made later. The mean activity for ${ }^{32} \mathrm{P}$ was $0.57 \%$, and is $0.33 \%$ higher than that reported by Chaplin (1954). This high mean value may have been due to the occasions when the labelled red cell suspension was left standing on the bench for up to half an hour before separation. In Chaplin's original method the suspension was centrifuged immediately. These results suggested that it is useful to test routinely the radioactivity level of the supernatant separated immediately at the end of preparation of the red cell suspension, and to review the red cell volume result with suspicion when the supernatant contains more than $1 \%$ of the total radioactivity.

The more detailed investigation of the rate of leakage in vitro of ${ }^{51} \mathrm{Cr}$ discussed above suggests that ${ }^{51} \mathrm{Cr}$-labelled stored red cells may be kept for up to four hours before being injected. This is a useful advantage over ${ }^{32} \mathrm{P}$ as a red cell label, as the need for immediate injection is removed.

Adequacy of Intravascular Mixing and Survival of Labelled Materials in the Circulation.-The concentration of label per unit volume of blood or plasma at various times after injection has shown whether mixing is complete and also defined the survival of the material in the circulation. It is important that the sample be taken at a time when mixing is virtually complete, and yet before significant loss of the injected material from the circulation has occurred. Noble and Gregersen (1946) found the average mixing time of 27 normal males to be nine minutes, of 40 patients not in "shock" to be seven minutes, and of 27 patients in "shock" to be 14 minutes. In our patients the small scatter of the results nine to 15 minutes after injection suggests that mixing was complete by this time.

In conditions where the circulation may be abnormal samples may be taken $10,15,20$, and 30 minutes after injection to look for unsuspected fluctuations in the concentration of labelled material. The theoretical possibilities of abnormal mixing after injury and the risks of failing to detect such abnormalities by repeated venous sampling have been discussed elsewhere (Topley et al., 1959).

The changes in concentration of the label later than 15 minutes after injection have been used to show the rate of disappearance, although continued poor mixing could not be excluded. The standard deviations show no difference between the scatter of the results during the first $\mathbf{4 8}$ hours compared with later. In each case the mean rate of disappearance during the first $\mathbf{4 8}$ hours was slightly greater than that found later, and all values are slightly greater than those reported by other workers. The mean rates of disappearance later than $\mathbf{4 8}$ hours after injury are slightly greater than those of Mollison (1956) for T-1824 in normal individuals, and those of Chaplin (1954) for ${ }^{32}$ P-labelled red cells. The recent work of Mollison (1956) also with ${ }^{32}$ P-labelled red cells is more in agreement with our findings. Although the rate of disappearance of ${ }^{51} \mathrm{Cr}$ has been reported as negligible (Mollison and Veall, 1955), we find it to be $0.17 \%$ per minute for 
observations before 48 hours after injury and $0.07 \%$ per minute for observations made later.

These rates of disappearance for the various labelled materials are very slightly greater than those used in the calculation of the red cell and plasma volumes published by Topley et al. (1959). Our evidence following injury supports the conclusions of Mollison (1956) and Wiklander (1956) on normal individuals that a normal average rate of disappearance of the labelled agent should be assumed rather than construction of a disappearance curve based on only two or three venous samples.

Assuming an average rate of disappearance, when and how often should venous samples be taken? Chaplin (1954) found slightly closer agreement between repeated red cell volume estimations in normal individuals when the results were calculated from two or more samples than when only one sample was used. The observations described above on the disappearance of the labelled material indicate that some results differed from the mean line by more than $\pm 15 \%$, and hence a red cell volume estimation may occasionally have been inaccurate by this amount. The smaller number of discrepancies nine to 15 minutes after injection suggests that a sample taken at this time may give a more accurate result than a sample taken later. A result based upon a single blood sample has the added advantage of simplification of the method leading to a quicker result. It is often advantageous, however, to take one or two samples during the ensuing half-hour to show any gross abnormalities and to accumulate evidence on the mixing time and rate of disappearance in the condition under investigation.

There is still very little information on the mixing time and the rate of disappearance of labelled materials in those patients with very severe, often fatal injuries, and more data are required on the validity of red cell volume estimations in these patients.

Ratio Between Body and Venous Haematocrits. -The concept of the body haematocrit and the possible reasons for it being about $90 \%$ of the venous haematocrit has been much discussed (Chaplin, Mollison, and Vetter, 1953 ; Mollison, 1956). The ratio is certainly affected by a number of different factors including errors in the red cell and plasma volume techniques. The close agreement between two red cell volume methods in parallel and the wider the scatter between two plasma volume estimations suggest a smaller error from the red cell volume techniques compared with the plasma volume methods. The ratio between the body and venous haematocrits did not show any greater variation during the first 48 hours after injury than later, but at all times variations did occur that could produce errors of more than $\pm 10 \%$ in a red cell volume calculated from a plasma volume and the haematocrit.

Reeve and Veall (1949), Berson and Yalow (1952), Chaplin et al. (1953), and Brady, Cooper, Colodzin, McClenathan, King, and Williams (1953) have reported a smaller range of ratios between the body and venous haematocrits in normal individuals than in our patients. Nachman, James, Moore, and Evans (1950) have reported a range of 0.76 to 1.02 (mean $=0.88$ ) in 38 surgical patients, and Wasserman, Yoh, and Rashkoff (1951) have described a similar range in normal individuals. These results have been reviewed by Wiklander (1956).

Methods in Parallel and Series-Many workers, including Mollison and Veall (1955), have shown good agreement $\left( \pm 5 \%\right.$ error) between ${ }^{32} \mathrm{P}$ and ${ }^{51} \mathrm{Cr}$ red cell volume estimations in parallel, and we have confirmed this finding at varying times after injury. Chaplin (1954) has shown similar agreement when ${ }^{32} \mathrm{P}$ red cell volume estimations were repeated at weekly intervals. Reilly, French, Lau, Scott, and White (1954) have shown sequential red cell volume estimations two hours apart using ${ }^{51} \mathrm{Cr}$ to have a scatter of -4.0 to $+10 \%$.

A clinical assessment described by Topley et al. (1959) suggests that the red cell volume methods in series following many common forms of injury are usually consistent to within $\pm 10 \%$.

Simultaneous plasma volume estimations using T-1824 and ${ }^{131}$ I-labelled albumin did not agree as closely as simultaneous red cell volume estimations. This result agrees with those of Crispell, Porter, and Nieset (1950), Brady et al. (1953), and Inkley, Brooks, and Krieger (1955), where approximately three-quarters of the results agreed to within $\pm 10 \%$. Aust, Chou, Marvin, Brackney, and Moore (1951) and Zipf, Webber, and Grove (1955) report a greater scatter. Which of the methods caused this scatter is unknown, although serial estimations using $\mathrm{T}-1824$ and ${ }^{131}$ I-labelled albumin by Crispell et al. (1950) suggest that the ${ }^{131} \mathrm{I}$ method is not much more accurate than the T-1824 method.

The results discussed so far suggest that each of the following methods has a place in the assessment of haemorrhage and oligaemia following injury. 
The ${ }^{32} \mathrm{P}$ Method.-The published technique of Chaplin (1954) has been modified in minor detail as described above. Mollison, Robinson, and Hunter (1958) have since modified the method so that only two hours are required for an estimation instead of three. Two reports have appeared indicating the dangers of particulate matter in the stock solution of ${ }^{32} \mathrm{P}$ (Harrison and Raymond, 1951 ; Lamerton and Harriss, 1951). The material supplied by the Radiochemical Centre, Amersham, is satisfactory in this respect and the precautions described above, including sterilization within 20 minutes of opening, prevents contamination with micro-organisms. The radiation dosage associated with the use of ${ }^{32} \mathrm{P}$ will be discussed below.

The ${ }^{51} \mathrm{Cr}$ Method.-The method of Mollison and Veall (1955) is well validated for labelling the patient's own cells. Much less information is available on the accuracy of the method when stored cells are used. Theoretically red cells stored in A.C.D. solution and then labelled with ${ }^{51} \mathrm{Cr}$ may produce false red cell volume estimations due to the disappearance of a significant number of labelled non-viable cells from the circulation within 15 minutes of intravenous injection. As these cells would be absent from the blood sample taken for the estimation the result will be falsely high. However, as described above, estimations in parallel with ${ }^{32} \mathrm{P}$ showed good agreement. There was no significant difference in the rate of disappearance of ${ }^{51} \mathrm{Cr}$ from the circulation when labelled stored cells were compared with labelled patients' cells. The experiments describing the low rate of leakage at room temperature of ${ }^{51} \mathrm{Cr}$ from labelled stored cells indicate that these cells can be kept for at least three hours before the test is performed. This is an advantage over ${ }^{32} \mathrm{P}$ labelled red cells, particularly when the laboratory is some distance from the ward.

It would therefore seem that ${ }^{51} \mathrm{Cr}$-labelled stored red cells less than 10 days old are clinically useful for estimating red cell volume. Meyer (1956) has suggested using Group $\mathbf{O} R$ h-negative red cells labelled with ${ }^{51} \mathrm{Cr}$. We have found stored cells of the appropriate $\mathrm{ABO}$ and $\mathrm{Rh}$ group of particular advantage in an emergency when venous sampling may be difficult due to oligaemic "shock."

The T-1824 Method.-The method of Reeve (1948) has been modified as described above by applying a correction for variations in optical density not due to $\mathrm{T}-1824$. This correction is particularly necessary in the hours immediately following injury, as lipaemia is then often present. Similar corrections for opacity have been recommended by Shapiro (1951) and Hamilton (1958). Gregersen (1951) shows the advantage of using a simple photo-electric instrument and has stressed the optical disadvantages of using a delicate spectrophotometer to measure opaque solutions. In practice, however, our simple method using a spectrophotometer has shown significantly less variation in the rate of disappearance of the dye compared with that when no opacity correction is made.

Most of the extraction methods, e.g., those of Allen, Ochoa, Roth, and Gregersen (1953) and of Hobsley and Dew (1958), are not much more accurate than careful direct methods using a correction of opacity and are more time consuming. The method described by Tornberg (1958) may be simple enough for emergency use, but it is doubtful whether its accuracy is any better that a direct method allowing for varying plasma opacity.

Repeated T-1824 plasma volume estimations are not completely without risk, due mainly to the possible effect of dye bound to living cells. Roberts (1954) reports a fatality from septicaemia following an injection of $\mathrm{T}-1824$, but there is no evidence that the plasma volume estimation was responsible. Cells of the reticulo-endothelial system readily engulf the dye, and Hueper and Ichniowski (1944) report adverse effects on liver, heart, and lung cells of dogs, cats, rabbits, and rats. Allen and Orahovats (1951) have shown a decreased oxygen consumption by liver slices exposed to T-1824. Although dog red cells have been shown by Allen and Gregersen (1953) to be lysed by 16-28 mg. of free dye, this concentration does not affect thrice washed human red cells. The dye bound to albumin had no effect on the red cells of any species. The blue colour of the skin caused by quantities of dye in excess of those usually given for a plasma volume estimation lasts a considerable time. The concentration of dye recommended by Gibson and Gregersen (1935) of 0.15 to $0.20 \mathrm{mg}$. per $\mathrm{kg}$. for a single plasma volume estimation appears to be without ill effects and is very much less than the amounts producing the harmful effects discussed above.

The advantage of the T-1824 method over that using ${ }^{131}$ I-labelled albumin is the absence of any radiation hazard. For the estimation of red cell volume both plasma volume methods have the disadvantage of being less accurate due to variations in the ratio between the body and venous haematocrits. The T-1824 method has 
the added disadvantage of requiring a large blood sample $(15 \mathrm{ml}$.) before the injection of the dye, which is sometimes not available in the presence of oligaemic "shock."

The ${ }^{131}$ I Method.-This method has been used as the simple quick " blood volume" guide, as it takes less laboratory time than any other method. All the evidence to date suggests that it is at least as accurate as the T-1824 method.

Radiation Dosages.-A limiting factor in the use of radioactive isotopes is the potential danger arising from the radiation emitted during their disintegration. Reeve and Veall (1949) have calculated that $1 \mu \mathrm{C}$ of ${ }^{32} \mathrm{P}$ per gram of tissue delivers a dosage of 875 r.e.p. during its complete radioactive life. Using these figures, the small dose of ${ }^{32} \mathrm{P}$ used for a red cell volume estimation of $2 \mu \mathrm{C}$ generally distributed in a $70-\mathrm{kg}$. adult gives a total dose of 0.025 r.e.p. This figure is based on the assumption of no excretion, but it is only a theoretical value as fairly rapid excretion does occur.

With ${ }^{51} \mathrm{Cr}$, Frank and Gray (1953) have calculated, using the formula of Marinelli, Quimby, and Hine (1948), that $25 \mu \mathrm{C}$ gives a total dose of 0.025 r.e.p. In the calculation it was assumed that no excretion occurred, that the $\gamma$ radiation irradiated the whole body, and that the very soft $x$ rays irradiated the blood and reticuloendothelial cells only.

The relatively rapid loss of ${ }^{32} \mathbf{P}$ from the circulation makes possible repeated estimations, e.g., daily, without an increase in the amount of radioactivity required for the test. This is in contrast to ${ }^{51} \mathrm{Cr}$, where the persistence of the label in the red cells makes it necessary to use twice the amount of activity for an estimation as was used for the previous estimation. The advantage that ${ }^{32} \mathrm{P}$ has in this respect is offset in emergency work because three hours are required for the determination compared with one and threequarters to two hours with ${ }^{51} \mathrm{Cr}$. The modification of the ${ }^{32} \mathrm{P}$ method by Mollison et al. (1958) should reduce this disadvantage.

A further reduction in radiation dosage to 0.009 r.e.p. is obtained by the estimation of plasma volume instead of red cell volume with ${ }^{131}$ I-labelled albumin.

The radiation dosages described above are less than administered for a distant chest radiograph, where average doses between 0.04 and 0.2 r.e.p. are used (Recommendations of the International Commission on Radiological Protection, 1954).

Risks of Contamination of Labelled Material.There is a theoretical risk of bacterial contamina- tion of the blood during the labelling procedure, and thus the possibility of a blood stream infection following its intravenous injection. Such risks might be increased if the research procedure of blood volume estimations became a routine. There has been no clinical evidence of such an infection from contaminated blood in the 1,000 tests performed in this laboratory. Reeve (1950) laid great emphasis on the need for reinjecting the blood within two hours of sampling to avoid gross bacterial contamination.

The greatest risk may be contamination of the stock solution of radioactive material. Such a risk can be reduced to negligible proportions by effective sterilization (M.R.C. Report, 1959) immediately after using the stock solution. A small sterilizer or pressure cooker in the same laboratory as that used for blood volume estimations ensures no delay in sterilization. The sterilizer can be checked by repeated temperature recordings during sterilization, by occasional checks with bacterial spores of known resistance to heat, and by the invariable use of "Browns" tubes (Kelsey, 1958 ; Lowbury, 1958).

\section{Summary}

Red cell volume estimations have been made at various times after injury using ${ }^{32} \mathrm{P}$ - and ${ }^{51} \mathrm{Cr}$ labelled red cells, and plasma volumes using either T-1824- or ${ }^{131}$ I-labelled albumin.

A survey of the amount of extracellular radioactivity, the disappearance curves of labelled materials from the circulation, the ratios between the body and venous haematocrits, and a combination of different methods in parallel led to the following conclusions:

(a) That there was no clinically significant difference in the technical accuracy during the first 48 hours after injury compared with later.

(b) That most of the results were not in error by more than $\pm 10 \%$.

(c) That direct red cell volume methods using ${ }^{32} \mathrm{P}$ and ${ }^{51} \mathrm{Cr}$ were considerably more accurate measures of red cell volume than the indirect method using a plasma volume and the haematocrit, and were therefore considerably more precise in the assessment of haemorrhage.

The technical details of routine red cell and plasma volume estimations after injury are discussed.

We should like to thank Drs. E. B. Reeve, P. L. Mollison, and $\mathrm{H}$. Chaplin for their help and advice at the beginning of this investigation on the methods of estimating blood volume. 
We are grateful for the help of Miss Janet Frost, B.Sc., in various laboratory experiments and in conjunction with Dr. Mary Fisher, Mrs. Ann Foster, and Mrs. Myra Evans in the red cell and plasma volume estimations.

We wish to acknowledge the helpful advice and criticism given by Mr. R. Clarke and Dr. J. P. Bull, Director of the Medical Research Council Industrial Injuries and Burns Research Unit. We thank the clinical staff of the Birmingham Accident Hospital for co-operation in the investigation of patients under their care.

We should also like to thank Mrs. M. Kilner for secretarial assistance, Miss Toni Boulter for preparation of the charts, and Mr. R. Gill and the Photographic Department for the photographic reproduction of these charts.

\section{REFERENCES}

Allen, T. H., and Gregersen, M. I. (1953). Amer. J. Physiol., 172, 377. And Orahovats, P. D. (1951). Ibid., 164, 123

Ochoa, M., Roth, R. F., and Gregersen, M. I. (1953). Ibid., 175,243

Aust, J. B., Chou, S. N., Marvin, J. F., Brackney, E. L., and Moore G. E. (1951). Proc. Soc. exp. Biol. (N.Y.), 77, 514

Berson, S. A., and Yalow, R. S. (1952). J. clin. Invest., 31, 572.

Brady, L. W., Cooper, D. Y., Colodzin, M., McClenathan, J. E. King, E. R., and Williams, R. (1953). Surg. Gynec. Obstet., 97 25 .

Brown, E., Hopper, J., and Wennesland, R. (1957). Ann. Rev. Physiol., 19, 231 .

Chaplin, H.'(1954). J. Physiol. (Lond.), 123, 22.

and Mollison, P. L. (1952). Blood, 7, 1227

and Vetter, H. (1953). J. clin. Invest., 32, 1309

Clarke, R., Davies, J. W. L., Fisher, M. R., and Topley, E. (1959) To be published.

Crispell, K. R., Porter, B., and Nieset, R. T. (1950). J. clin. Invest.,

Fisher, M. R. (1958). Clin. Sci., 17, 181.
Frank, H., and Gray, S. J. (1953). J. clin. Invest., 32, 991

Gibson, J. G., and Gregersen, M. I. (1935). Amer, J. Physiol, 113, 50

Grant, R. T., and Reeve, E. B. (1951). Spec. Rep. Ser. Med. Res. Coun. (Lond.), No. 277.

Gregersen, M. I. (1951). Ann. Rev. Physiol., 13, 397.

Hamilton, L. H. (1958). J. Lab. clin. Med., 52, 762.

Harrison, G. E., and Raymond, W. H. A. (1951). Brit. med. J., 2, 930.

Hobsley, M., and Dew, E. D. (1958). J. clin. Path., 11, 451.

Hueper, W. C., and Ichniowski, C. T. (1944). Arch. Surg. (Chicago), 48,17 .

Inkley, S. R., Brooks, L., and Krieger, H. (1955). J. Lab. clin. Med., 45, 841 .

Kelsey, J. C. (1958). Personal communication.

Lamerton, L. F., and Harriss, E. B. (1951). Brit. med. J., 2, 932

Lowbury, E. J. L. (1958). Personal communication.

Marinelli, L. D., Quimby, E. H., and Hine, G. J. (1948). Amer. J. Roentgenol., $59,260$.

Meyer, L. M. (1956). J. Amer. med. Ass., 160, 1312.

Mollison, P. L. (1956). Blood Transfusion in Clinical Medicine, 2nd ed. Blackwell Scientific Publications. Oxford. and Veall, N. (1955). Brit. J. Haemat., 1, 62.

Robinson, M. A., and Hunter, D. A (1958). Lancet, 1, 766.

M.R.C. Report (1959). "Sterilisation by Steam under Increased Pressure," Lancet, 1, 425.

Nachman, H. M., James, G. W., Moore, J. W., and Evans, E. I. (1950). J. clin. Invest., 29, 258.

Noble, R. P., and Gregersen, M. I. (1946). Ibid., 25, 158.

Porat, B. T. D. von (1951). Acta med. scand., 140, Suppl. 256.

Reeve, E. B. (1948). Nutr. Abstr. Rev., 17, 811.

(1950). Personal communication.

and Veall, N. (1949). J. Physiol. (Lond.), 108, 12

(1957). Ann. N.Y. Acad. Sci., 70, 137

Recommendations of International Commission on Radiological Protection (1954). Brit.J. Radiol., Suppl. 6.

Reilly, W. A., French, R. M., Lau, F. Y. K., Scott, K. G., and White, W. E. (1954). Circulation, 9, 571.

Roberts, L. N. (1954). Canad. med. Ass. J., 71, 489.

Shapiro, S. L. (1951). Science, 114, 73.

Topley, E., Fisher, M. R., Davies, J. W. L., and Clarke, R. (1959). To be published.

Tornberg, A. (1958). Acta med scand, 161, 69.

Veall, N., Pearson, J. D., and Hanley, T. (1955). Brit. J. Radiol., $28,633$.

Wasserman, L. R., Yoh, T. F., and Rashkoff, I. A. (1951). J. Lab. clin. Med., 37, 342 .

Wiklander, O. (1956). Acta chir. scand., Suppl. 208.

Zipf, R. E., Webber, J. M., and Grove, G. R. (1955). J. Lab. clin. Med. 45,800 . 